\title{
MENARA RIAU
}

Jurnal IImu Pengetahuan dan Pengembangan Masyarakat Islam

ISSN: 2085-8833 | Vol. 14 No.1 April, 2020, pp. 11-21

http: http://ejournal.uin-suska.ac.id/index.php/Menara/index

\section{Pemberdayaan Peternak Pada Suku Akit Melalui Pemanfaatan Bahan Baku Pakan Lokal Tepung Biji Karet Fermentasi Sebagai Ransum Pellet Puyuh Petelur}

\author{
Anwar Efendi Harahap1, Oksana1, Bakhendri Solfan', Irsyadi Siradjuddin² \\ 1Fakultas Pertanian dan Peternakan Universitas Islam Negeri Sultan Syarif Kasim Riau \\ ${ }^{2}$ Fakultas Sains dan Teknologi Universitas Islam Negeri Alauddin Makasar \\ email : harahapa258@gmail.com
}

\begin{abstract}
Abstrak
Suku Akit adalah suku asli Pulau Rupat yang terbiasa hidup berburu dan meramu. Suku Akit merupakan salah satu komunitas adat terpencil (KAT) yang ada di Provinsi Riau. Pengabdian ini bertujuan memanfaatkan dan mengolah biji karet dengan teknologi pellet sebagai pakan ternak ransum puyuh petelur sebagai usaha meningkatkan kesejahteraan masyarakat. Metode pengabdian adalah metode Community Based Research (CBR) adalah metode dimana masyarakat turut andil dalam proses penelitian dan pengabdian ini. Hasil menunjukkan bahwa kegiatan pengabdian menghasilkan 80 $90 \%$ umpan balik dari masyarakat, walaupun sebagian besar masyarakat memiliki tingkat pendidikan yang rendah tetapi masih mudah memahami materi. Selanjutnya konsumsi ransum selama pemeliharaan puyuh yaitu 19,65-22,01\%, berat telur puyuh 6,66 - 8,35 \% dan konversi ransum 2,36-3,43. Kesimpulan pengabdian ini adalah ransum pellet fermentasi hingga $6 \%$ tepung biji karet dapat dijadikan sebagai pakan puyuh petelur dengan model pengabdian community based research (CBR) memotivasi peternak dalam meningkatkan usaha beternak puyuh secara berkelanjutan
\end{abstract}

Kata Kunci: suku, akit, puyuh, peternak, biji karet

\section{Abstract}

The Akit tribe is the original tribe of Rupat Island who is used to living hunting and gathering. The Akit tribe is one of the remote indigenous communities (KAT) in Riau Province. This service aims to utilize and process rubber seeds with pellet technology as animal feed for laying quail rations as an effort to improve the welfare of the community. The service method is the Community Based Research (CBR) method, which is a method where the community takes part in this research and service process. The results show that community service activities generate 80 -90\% feedback from the community, even though most people have low levels of education but still easily understand the material. Furthermore, the ration consumption during quail maintenance was $19.65-22.01 \%$, the weight of quail eggs was $6.66-8.35 \%$ and the ration conversion was $2.36-3.43$. The conclusion of this service is that fermented pellet ration up to 6\% of rubber seed flour be used as laying quail feed with the community based research (CBR) service model to motivate breeders to increase their business in raising quail in a sustainable

Key word: Tribe, akit, quail, farmer, Rubber Seed 
Pemberdayaan Peternak Pada Suku Akit Melalui Pemanfaatan Bahan Baku Pakan Lokal Tepung Biij Karet Fermentasi Sebagai Ransum Pellet Puyuh Petelur

\section{Pendahuluan}

Suku Akit adalah suku asli Pulau Rupat yang terletak di kabupaten Bengkalis Povinsi Riau, suku Akit terbiasa hidup berburu dan meramu. Suku Akit merupakan salah satu komunitas adat terpencil (KAT) yang ada di provinsi Riau. Salah satu dari karakter KAT adalah pengetahuan dan data yang terbatas, wilayah yang sulit terjangkau dan pemahaman adat yang kuat pada masyarakat adat. Berdasarkan Keppres nomor 111/1999) tentang pembinaan kesejahteraan sosial komunitas Adat Terpencil dan Inpres No.3 Tahun 2010 tentang perlindungan Kelompok Marginal maka, KAT merupakan kelompok sosial yang bersifat lokal dan terpencar serta kurang atau belum terlibat dalam jaringan dan pelayanan, baik secara sosial, ekonomi maupun politik. Dari berbagai literatur terungkap bahwa penyebab dasar kemiskinan pada KAT adalah masalah struktural seperti kebijakan dan peraturan yang tidak berpihak pada masyarakat adat. Kondisi kemiskinan pada suku akit yang terletak di Kabupaten Bengkalis ternyata bertolak belakang dengan kondisi sumber daya alam yang dimiliki salah satunya yang berasal dari perkebunan karet. Berdasarkan data tahun 2010, luas area tanaman karet di daerah ini, baik itu yang berasal dari perkebunan rakyat maupun perusahaan perkebunan sebanyak 32.192 ha yang tersebar di seluruh kecamatan dengan produksi 25.089 ton. Meskipun produksi karet di kabupaten Bengkalis besar, namun saat ini pengembangan industri hulu dan hilir karet dalam menopang perkembangan masyarakat belum ada. Produk yang dihasilkan hanya sebatas getah alam, padahal tanaman karet dapat menghasilkan limbah biji karet yang digunakan sebagai bahan pakan ternak unggas yaitu puyuh petelur.

Adapun riset pendahuluan yang telah dilaksanakan oleh Lasmawati (2011) bahwa tepung biji karet masih dapat diberikan sebagi ransum puyuh petelur hingga level 8\%. Pemanfaatan tepung biji karet sebagai bahan pakan membutuhkan sentuhan teknologi karena biji karet mempunyai keterbatasan untuk digunakan sebagai pakan karena memiliki kandungan HCN (Sianida). Oleh karena itu, sebelum diberikan kepada puyuh petelur sebagai pakan perlu dilakukan pengolahan melalui proses fermentasi. Selanjutnya untuk menjamin kualitas pakan puyuh petelur berbahan dasar biji karet yang terfermentasi tetap terjaga dan kontiniu maka dapat dilakukan dengan proses mekanis yaitu dengan metode pelleting. Pakan - pakan dalam bentuk pellet yang diproduksi secara mandiri diharapkan dapat memperbaiki industri pakan karena industri pakan ternak merupakan industri hulu yang memegang peranan sangat vital dalam pengambangan industri peternakan. Berdasarkan kondisi tersebut, kami telah melaksanakan kegiatan pemberdayaan masyarakat peternak pada suku Akit (suku asli pulau Rupat) berbasis penelitian menggunakan bahan pakan lokal yaitu tepung biji karet

\section{Metode}

Subjek kegiatan pengabdian adalah masyarakat terutama petani karet di Desa Pulau Rupat Kecamatan Rupat Kabupaten Bengkalis. Pengabdian ini diawali dengan pembuatan pellet dan analisis fisik dilaksanakan di lokasi kajian. Analisa Nutrisi pellet dilaksanakan di Laboratorium Nutrisi dan Teknologi Pakan Fakultas Pertanian dan Peternakan Universitas Islam Negeri Sultan Syarif Kasim Riau. Metode pengabdian yang digunakan adalah pengabdian berbasis penelitian (Community Based Research) 


\section{Kondisi Saat Ini Masyarakat Dampingan}

Orang Akit atau orang Akik, adalah kelompok sosial yang berdiam di daerah Pesisir Riau termasuk di Kabupaten Karimun , Provinsi Kepulauan Riau. Sebutan "Akit" diberikan kepada masyarakat ini karena sebagian besar kegiatan hidup mereka berlangsung di atas rumah rakit. Dengan rakit tersebut mereka berpindah dari satu tempat ke tempat lain di pantai laut dan muara sungai. Mereka juga membangun rumahrumah sederhana di pinggir-pinggir pantai untuk dipergunakan ketika mereka mengerjakan kegiatan di darat yang mencoba menanamkan pengaruhnya di daerah ini tercatat mengalami beberapa perlawanan dari orang Akit. Pasukan Akit dikenal dengan senjata tradisional berupa panah beracun dan sejenis senjata sumpit yang ditiup (Wikipedia, 2012).

Mata pencaharian pokok orang Akit adalah menangkap ikan, mengumpulkan hasil hutan, berburu binatang, dan meramu sagu. Orang Akit tidak mengenal sistem perladangan secara menetap. Pengambilan hasil hutan yang ada di tepi-tepi pantai biasanya disesuaikan dengan jumlah kebutuhan. Penangkapan ikan atau binatang laut lainnya mereka lakukan dengan cara sederhana, misalnya dengan memasang perangkap ikan (bubu). Mengikuti penjelasan tokoh masyarakat dari suku Akit ( Ewa Bekuk ) menceritakan diperkirakan pada abat 17 Masehi, ketika Sultan Siak Sri Indrapura bertahta sekelompok suku yang bermukim di sepanjang Sungai Mandau bermohon kepada Sultan agar diberi izin dan sekaligus dicarikan tempat untuk pindah ke daerah baru yang mereka idam-idamkan dan masih masuk dalam wilayah kekuasaan Sultan, dengan alasan kehidupan mereka di sepanjang Sungai Mandau sering di ganggu oleh binatang Buas dan ada kabar akan masuknya Belanda ke kawasan kerajaan Siak. Permohonan mereka di izinkan oleh Sultan dan mereka di suruh menghadap Megat Alang Dilaut sebagai penguasa laut yang berkedudukan di Bukitbatu untuk menyampaikan keinginan mereka. Megat Alang Dilaut menunjuk Pulau Bengkalis untuk tempat tinggal di daerah baru (Ghofur, 2014).

Masyarakat miskin di pesisir yang jumlahnya mencapai 7,8 juta jiwa tersebar di 10 ribu desa pesisir yang sangat tertinggal, baik dari sekor ekonomi, pendidikan, maupun sektor yang lain. Hal ini menandakan bahwa paradigma untuk membangun daerah pesisir masih rendah di dalam masyarakat kita. Fakta sosial yang juga mewarnai kehidupan masyarakat pesisir termasuk kehidupan suku Akit di Teluk sitimbul adalah adanya struktur sosial yang sangat terikat dengan toke (tengkulak) atau dalam arti harfiah orang yang mempunyai modal (Ghofur, 2014).

Salah satu masalah yang timbul yang sangat nyata terjadi adalah, pendapatan suku akit secara perlahan akan mengalami penurunan. Kehidupan nelayan memang sangat rentan.Terlebih ketika mereka semata mata bergantung pada hasil tangkapan ikan di laut.Ketika laut semakin sulit memberikan hasil yang maksimal, maka hal ini merupakan salah satu ancaman bagi keberlangsungan kehidupan ekonomi pada masamasa selanjutnya. Kehidupan yang semakin sulit itu ditandai dengan peningkatan jumlah alat tangkap yang semakin banyak tapi tidak diiringi dengan peningkatan produksi hasil tangkapan (Ghofur, 2014). Rentannya kehidupan suku akit ini bukan hanya menyangkut aset kebendaan atau materi saja, akan tetapi ketidakmampuan 
nelayan untuk mengelola keuangan mereka adalah salah satu pemicu masalah kemiskinan suku akit . Potret rumah tangga suku akit biasanya diwarnai oleh pola gaya hidup yang belum sepenuhnya berorientasi pada masa depan.

\section{Kondisi Dampingan Yang Diharapkan}

Adapun kondisi dampingan yang diharapkan saat ini sebagai berikut: Kegiatan pengabdian ini diuapayakan dapat merubah kondisi perekonomian masyarakat suku akit dengan merubah pola beternak puyuh petelur yang masih bersifat tradisional menjadi beternak sebagai usaha utama dengan mengoptimalisasi tepung biji karet fermentasi sebagai pakan pellet melalui penyusunan ransum sehingga peternak suku akit memilki keinginan untuk beternak puyuh petelur dengan skala besar.

\section{Strategi Pelaksaaan}

Adapan strategi pelaksanaan yang kami tawarkan sebagai berikut:

1. Melakukan penelitian lanjutan dengan kelompok peternak yang ada di suku akit pada komuntas adat terpencil (KAT) Pulau Rupat Bengkalis melalui pemanfaatan tepung biji karet fermentasi berbentuk pellet sebagai pakan puyuh petelur hingga level diatas $8 \%$.

2. Melakukan usaha beternak puyuh petelur dengan pemanfaatan tepung biji karet sekaligus merubah sistem beternak puyuh dan pengolahan pakan secara modern

3. Pelatihan penyusunan ransum puyuh petelur sehingga model penyusunan ransum secara tradisional dapat ditinggalkan.

Untuk pengambilan bahan biji karet dipeoleh dari Pulau Rupat Kabupaten Bengkalis Provinsi Riau. Untuk pengujian kualitas fermentasi dan Nutrisi limbah bahan biji karet dilaksanakan di Laboratorium Nutrisi dan Teknologi Pakan serta Laboratorium Patologi, Entomologi dan Mikrobiologi Fakultas Pertanian dan Peternakan UIN Sultan Syarif Kasim Riau. Selanjutnya untuk pengujian formulasi ransum dalam bentuk pellet terhadap puyuh petelur dilaksanakan Pulau Rupat Kabupaten Bengkalis Provinsi Riau

Pengabdian yang dilakukan berbasis CBR (comuunity based research) pada masyarakat suku akit. Metode yang digunakan dalam pengabdian ini adalah analisa deskriptif. Adapun total puyuh yang digunakan sebanyak 120 ekor. Adapun pemberian perlakuan tepung biji karet berbentuk pellet terhadap puyuh petelur adalah sebagai berikut :

R1 : Ransum Pellet Fermentasi dengan 0\% Tepung Biji Karet

R2 : Ransum Pellet Fermentasi dengan 2\% Tepung Biji Karet

R3 : Ransum Pellet Fermentasi dengan 4\% Tepung Biji Karet

R4 : Ransum Pellet Fermentasi dengan 6\% Tepung Biji Karet

Peubah yang akan diamati dalam pengabdian berbasis pengabdian ini adalah:

1. Konsumsi ransum, dihitung dalam gram/ekor/hari. Konsumsi ransum dihitung setiap hari dengan cara mengurangkan jumlah ransum yang diberikan dengan ransum sisa. 
2. Produksi telur hen day dihitung dengan membandingkan produksi telur setiap hari dengan jumlah burung puyuh pada hari tersebut dikali seratus persen.

4. Konversi ransum dihitung dengan membandingkan jumlah ransum yang dikonsumsi setiap hari dengan berat telur yang dihasilkan pada hari tersebut.

\section{Hasil dan Pembahasan}

Untuk mencapai lokasi pengabdian yang terdapat dipulau Rupat kabupaten Bengkalis memiliki berbagai kesulitan. Kesulitan utama adalah masalah transportasi dimana pemerataan pembangunan transportasi yang belum merata yang membutuhkan biaya yang mahal. Untuk lebih jelasnya kondisi lokasi tim pengabdi saat menuju Lokasi pengabdian

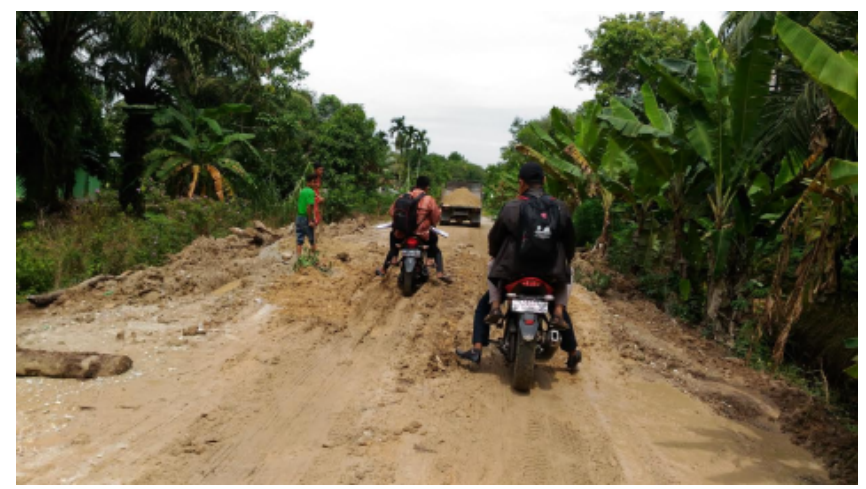

Gambar 1. Kondisi Jalan Menuju Lokasi Pengabdian

Kondisi jalan ini yang sangat rusak ini harus dilalui oleh tim pengabdi scara hatihati karena bisa menyebabkan terjatuh, selanjutnya jalan ini tidak bisa dilalui kendaraan roda 4 atau mobil, hanya bisa dilalui oleh kendaraan roda 2 atau motor. Selanjutnya mayoritas jalan masih berupa tanah dan bila kondisi jalan dalam keadaan basah maka jalan tersebut hampir tidak dapat dilalui. Kegiatan Pengabdian kepada Masyarakat dilaksanakan di pada suku akit yang terdapat di Pulau Rupat memperoleh cukup umpan balik atas pelaksanaan rencana pengabdian yang telah dibuat. Selanjutnya evaluasi dengan umpan balik hasil pelaksanaan bermanfaat dalam perumusan langkah-langkah perbaikan. Evaluasi pengabdian dapat dilaksanakan dengan cara terlebih dahulu menetapkan indikator indikator kinerja. Oleh sebab itu, indikator kinerja sebaliknya merupakan besaran-besaran yang dapat diukur dengan relatif mudah dan murah. Pengukuran tingkat kinerja dalam evaluasi meliputi; pengukuran kinerja kegiatan, pengukuran kinerja program, dan pengukuran kinerja kebijakan. Kegiatan Pelatihan pengembangan peternakan pada suku akit yang terdapat di Pulau Rupat Kabupaten Bengkalis menghasilkan 80 - $90 \%$ umpan balik dari masyarakat, walaupun sebagian besar masyarakat pada suku akit yang terdapat di Pulau Rupat memiliki tingkat pendidikan yang sangat rendah tetapi masih mudah memahami materi pelatihan yang disajikan oleh narasumber. Untuk lebih jelasnya kondisi awal masyarakat suku akit pulau Rupat dapat dilihat pada Gambar dibawah ini. 


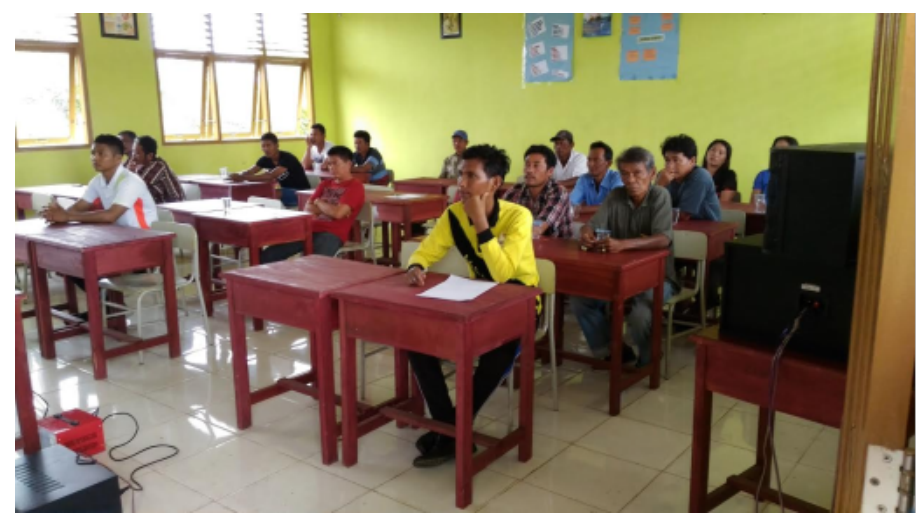

Gambar 2. Kondisi Masyarakat Suku Akit pada Saat Penyuluhan

Kegiatan pelatihan dimulai dengan presentasi narasumber yang berkaitan dengan pemeliharaan, budidaya dan pembibitan ternak burung puyuh. Cakupan berbagai kegiatan untuk dapat memberikan pemahaman pemeliharaan, budidaya dan pembibitan ternak burung puyuh untuk meningkatkan pengetahuan masyarakat suku akit yang terdapat di Pulau Rupat Kabupaten Bengkalis tentang beternak puyuh . Berdasarkan analisis bahwa kegiatan pelatihan memiliki faktor - faktor pendukung antara lain kemauan dan kerja keras masyarakat suku akit untuk belajar bagaimana cara beternak dengan baik dengan konsep ipteks yang terbarukan, sifat kebersamaan masyarakat suku akit untuk mengelola unit usaha beternak puyuh serta koordinasi yang jelas antara masyarakat suku akit sehingga semua masyarakat suku akit mempunyai rasa memiliki terhadap ternak yang ada.

Dari Faktor - faktor pendukung kegiatan pelatihan tersebut maka dampak langsung yang dapat dirasakan masyarakat suku akit adalah menyediakan informasi tentang peluang investasi di bidang usaha beternak puyuh yang sangat potensial untuk dikembangkan mengingat kebutuhan akan telur meningkat. Menyediakan informasi dan pengetahuan untuk mengembangkan usaha beternak puyuh terutama di masyarakat suku akit sedangkan dampak tidak langsung adalah model usaha beternak puyuh dengan manajemen pemeliharaan ternak yang efisien dan berkesinambungan. Untuk lebih jelasnya kondisi narasumber memberikan penyuluhan dapat dilihat pada Gambar dibawah ini

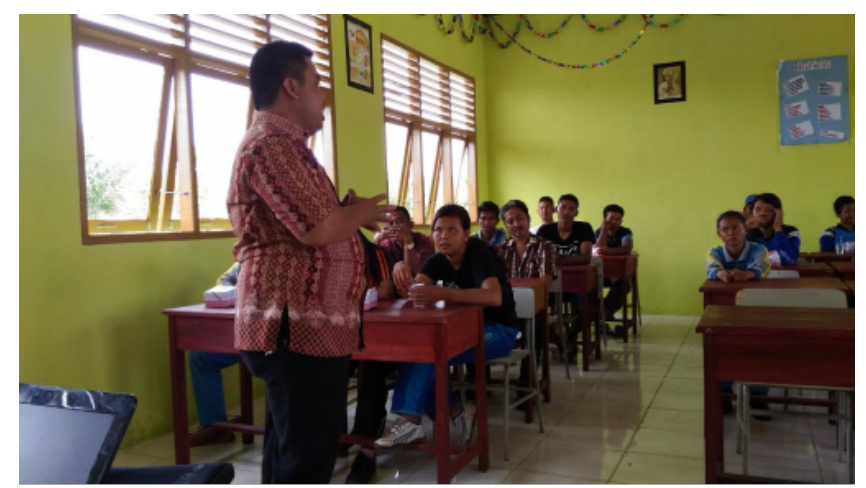

Gambar 3. Narasumber Saat Memberikan Materi Penyuluhan

Kegiatan ini menjadi pembuktian dan tolak ukur bahwa usaha usaha beternak puyuh dan pengembangannya bukan hanya sebagai usaha sambilan (tabungan) 
melainkan dapat dijadikan sebagai kegiatan utama untuk memenuhi kebutuhan hidup sehari - hari dengan catatan harus ada keseriusan antara semua pihak baik. Untuk lebih jelasnya pembukaan dan pemberian materi pengabdian tentang beternak puyuh dapat dilihat pada Gambar 4 dibawah ini

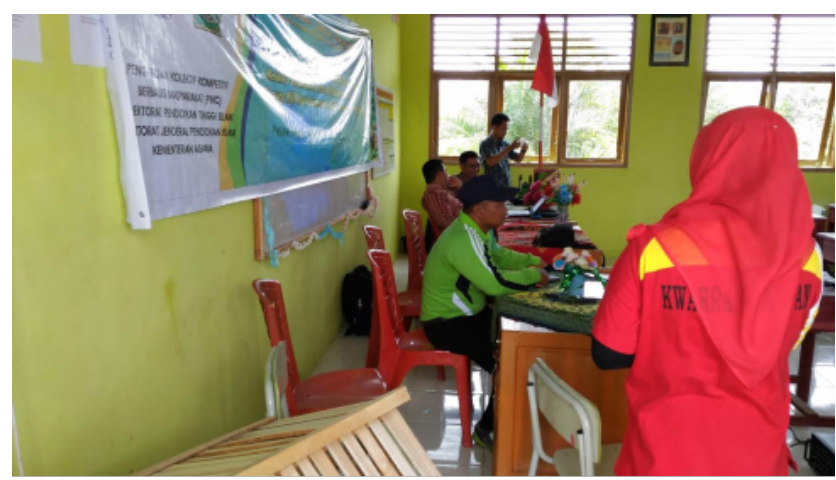

Gambar 4. Narasumber Saat Memberikan Materi Penyuluhan

Selanjutnya tim pengabdi juga memberikan pelatihan beternak puyuh langsung terhadap anak- anak suku akit. Untuk lebih jelasnya dapat dilihat pada Gambar dibawah ini.

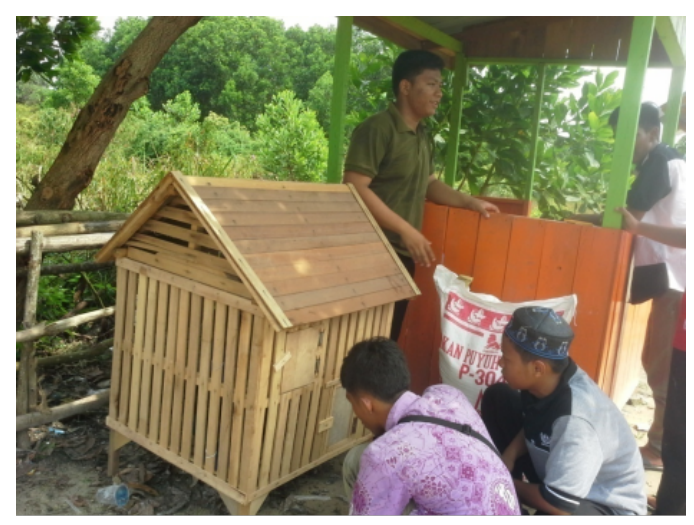

Gambar 5. Pelatihan Perkandangan Puyuh Terhadap Anak- Anak Suku Akit

\section{Konsumsi Ransum}

Konsumsi ransum dapat dipengaruhi oleh kualitas dan kuantitas ransum, umur, aktifitas ternak, palatabilitas ransum, tingkat produksi dan pengelolaannya dapat dilihat pada Gambar dibawah ini 


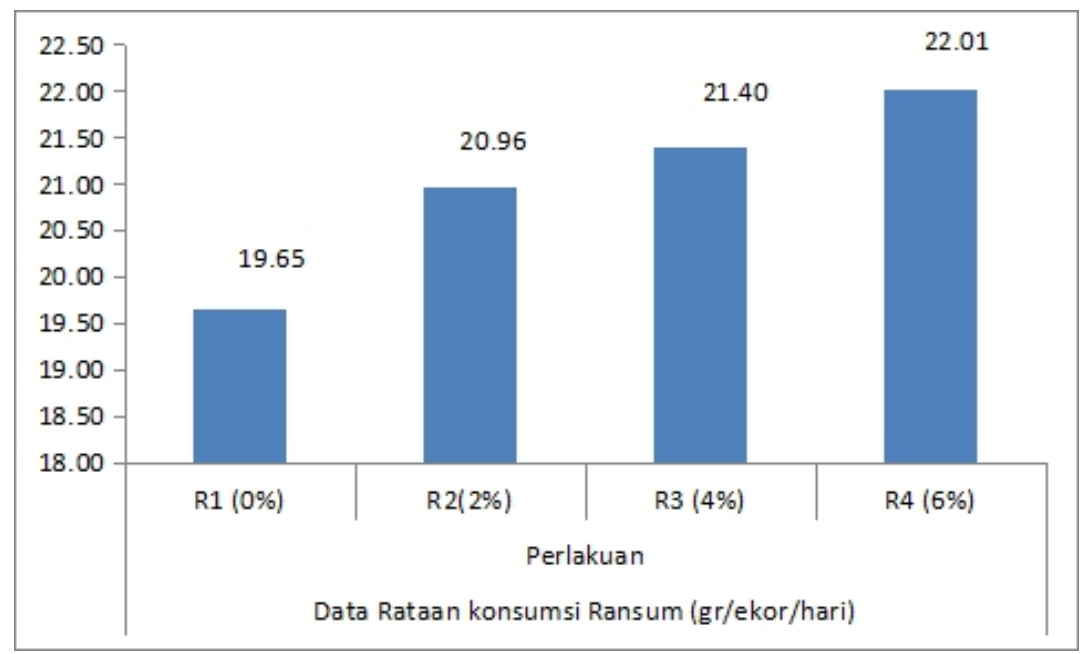

Gambar 6. Konsumsi Ransum Puyuh Petelur Selama Pengabdian

Pada Gambar menunjukkan bahwa konsumsi ransum pada perlakuan R4 (22.01/gr/ekor/hari) lebih tinggi dibandingkan dengan perlakuan lainnya. Hal ini kemungkinan disebabkan kebutuhan energi belum terpenuhi secara maksimal walaupun pada penggunaan ransum dengan tepung biji karet yang paling tinggi. Jumlah makanan yang dimakan tiap harinya cenderung berhubungan erat dengan kadar energinya. Bila konsentrasi protein yang tetap terdapat dalam semua ransum, maka ransum yang mempunyai konsentrasi energi metabolis tinggi akan menyediakan protein yang kurang dalam tubuh unggas karena rendahnya jumlah makanan yang dimakan. Sebaliknya, bila kadar energi kurang maka unggas akan mengkonsumsi makanan untuk mendapatkan lebih banyak energi, akibatnya kemungkinan unggas akan mengkonsumsi protein yang berlebihan (Tillman et al, 1989). Faktor utama yang mempengaruhi konsumsi ransum unggas adalah kandungan energi metabolisme dan unggas akan berhenti makan apabila kebutuhan energi sudah terpenuhi walaupun tembolok belum penuh. Hasil penelitian ini hampir sama dengan hasil penelitian Ali dkk., (2019) menghasilkan nilai konsumsi ransum sebesar 17. 12 - 21.03 gr/ekor/hari menggu pada tingkat kepadatan yang berbeda

\section{Konversi Ransum}

Konversi Ransum Menunjukkan Tingkat Efisiensi Penggunaan Ransum. Konversi Ransum Adalah perbandingan jumlah ransum yang dikonsumsi pada satu minggu dengan pertambahan bobot badan pada minggu itu dapat dilihat pada Gambar dibawah ini 


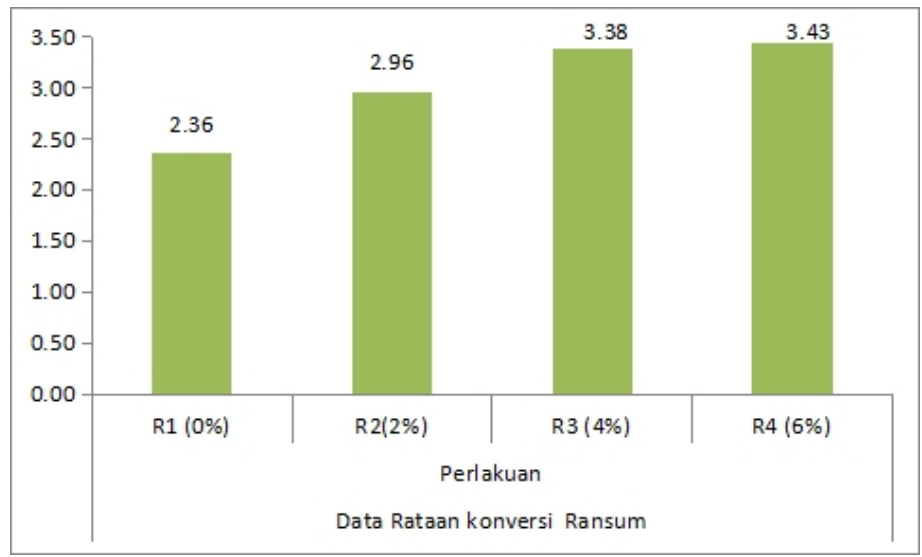

Gambar 7. Konversi Ransum Puyuh Petelur Selama Pengabdian

Pada Gambar menunjukkan bahwa konversi ransum pada perlakuan R4 (3.43) lebih tinggi dibandingkan dengan perlakuan lainnya. Angka konversi ransum menunjukkan tingkat penggunaan ransum dimana jika angka konversi semakin kecil maka penggunaan ransum semakin efisien dan sebaliknya jika angka konversi besar maka penggunaan ransum tidak efisien. Angka konversi ransum dipengaruhi oleh strain dan faktor lingkungan seperti seluruh pengaruh luar termasuk didalamnya faktor makanan terutama nilai gizi rendah (Lestari, 1992). Konversi ransum dipengaruhi oleh faktor-faktor seperti : umur ternak, bangsa, kandungan gizi ransum, keadaan temperatur dan keadaan unggas (Anggorodi, 1995).

Semakin baik mutu pakan semakin kecil pula konversi pakannya. Baik tidaknya mutu pakan ditentukan seimbang tidaknya zat-zat gizi dalam pakan itu yang diperlukan oleh burung puyuh. Pakan yang kekurangan salah satu unsur gizi akan mengakibatkan burung puyuh memakan pakannya secara berlebihan untuk mencukupi kekurangan zat yang diperlukan tubuhnya. Hasil penelitian ini lebih tinggi dibandingkan dengan hasil penelitian Herlinae dan Hermina, (2016) yang menyatakan konversi ransum dengan pemberian probiotik pada pertumbuhan dan produksi telur berkisar 1.90 - 7.70

\section{Berat Telur}

Berat telur merupakan sifat kualitatif yang dapat diturunkan. Jenis pakan, jumlah pakan, lingkungan kandang serta besar tubuh induk sangat mempengaruhi berat telur yang dihasilkan. Untuk lebih jelasnya dapat dilihat pada Gambar dibawah ini

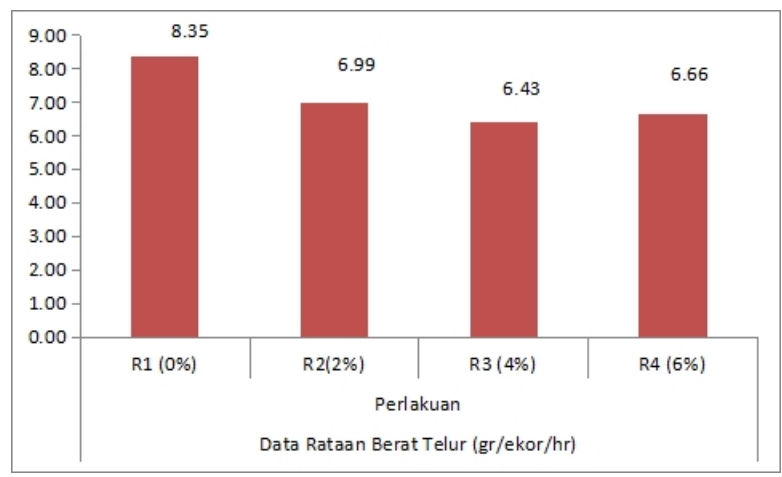


Gambar 8. Berat Telur Puyuh Selama Pengabdian

Pada Gambar menunjukkan bahwa berat telur pada perlakuan R1 (8.35 gr/ekor/hari) lebih tinggi dibandingkan dengan perlakuan lainnya. Hal lain yang mempengaruhi berat telur adalah masa bertelur. Produksi pertama dari suatu periode bertelur menghasilkan bobot telur yang lebih rendah dibanding telur berikutnya pada periode yang sama (Listiyowati dan Roospitasari, 2009). Hasil penelitian ini lebih rendah dibandingkan dengan penelitian Widodo $d k k$, (2019) dengan berat telur sebesar $8.76 \mathrm{gr} / \mathrm{ekor} / \mathrm{hari}$ dengan penggunaan probiotik Candida utilis pada ransum puyuh petelur juga lebih rendah dibandingkan hasil penelitian Novita $d k k$, (2019) menghasilkan bobot telur yang diberikan tepung biji karet hingga level $18 \%$ menggunakan ransum komersil berikisar 11.23 - $11.74 \mathrm{gr} / \mathrm{ekor} / \mathrm{hari}$.

\section{Simpulan}

Seluruh peserta pengabdian masyarakat pada Suku Akit mengikuti pelatihan secara serius dan semangat ditandai dengan banyak umpan balik atas kegiatan Pengabdian Masyarakat tersebut. Pengabdian ini diharapkan menjadi cikal bakal usaha peternakan kolektif yang mandiri dan berorientasi bisnis profit melalui pendampingan, pengawalan, aplikasi teknologi dan informasi, transfer ilmu pengetahuan

\section{Referensi}

Ali. L, Syukri I., Gubal., \& Saleh, E.J. (2019). Penampilan Produksi Telur Burung Puyuh Terhadap Tingkat Kepadatan yang Berbeda. Jambura Journal of Animal Science. 2(1): 8-12. https://doi : 10.35900/jjas.v2i1.2346

Ghofur. (2004). Problematika Pembangunan Pulau Terluar dan Pemberdyaan Masyarakat di kecamatan Rupat Utara. Media Komunikasi Umat Bergama, Vol.6, No.1 Januari-Juni 2014. UIN Suska Riau

Herlinae \& Yemima. (2016). Efektifitas Berbagai Probiotik Kemasan Terhadap Pertumbuhan dan Produksi Burung Puyuh (Coturnix coturnix japonica). Jurnal Ilmu Hewani Tropika. 5(2): 95 -100

Heriyanto M, (2012). Formulasi Kebijakan Pembangunan Pulau Terluar. Universitas Riau

Listiyowati, E dan Roospitasari, K. (2009). Tatalaksana Budidaya Puyuh Secara Komersial. PT Penebar Swadaya. Jakarta.

McDonald P, Henderson AR, Heron SJE. (1991). The Biochemistry of Silage. Second Edition, Marlow: Chalcombe.

NRC (National Research Council). (1977). Nutrient Requirement of Poultry. USA

Novita. R., Herlina. B., \& Permata. L. (2019). Level Pemberian Tepung Biji Karet Terhadap produksi dan Bobot Telur Burung Puyuh (Coturnix coturnix Japonica). Jurnal Biosilampari: Jurnal Biologi. 1(2): 87 - 94. https://doi: 10.31540/biosilampari.v1i2.248

Rasyaf, M. (2002). Bahan Makanan Unggas di Indonesia. Kanisius. Yogyakarta 
Widodo. E., Sjofjan. O., \& Roro. R.J A.G. (2019). Efek Probiotik Candida utilis Penampilan Produksi Burung Puyuh Petelur (Coturnix coturnix japonica). Jurnal Ilmilah Filia Cendikia. 4(1): 23- 31. https://doi: 10.32503 /fillia.v4i1.414 